\title{
Predicting the age of sardine juveniles (Sardina pilchardus) from otolith and fish morphometric characteristics
}

\author{
Andreia V. Silva ${ }^{1,2}$, Isabel Meneses ${ }^{1}$, Alexandra Silva ${ }^{1}$ \\ ${ }^{1}$ Instituto Português do Mar e da Atmosfera, Avenida de Brasília, 1449-006 Lisboa, Portugal. E-mail: avsilva@ipma.pt \\ ${ }^{2}$ Present address: Instituto Português do Mar e da Atmosfera, Divisão de Modelação e Gestão e Recursos da Pesca, \\ Avenida de Brasília, 1449-006 Lisboa, Portugal.
}

\begin{abstract}
Summary: An age prediction model based on individual morphometric characteristics (total length; weight) and otolith morphometric characteristics (diameter; weight) was investigated for juvenile sardine, Sardina pilchardus (Walbaum, 1792). Juveniles were collected from northern Portugal between May 2004 and January 2005. Daily growth rings were counted on the otoliths of 114 juveniles of 7-16 cm total length. The sample was divided into a training sample used to develop the age prediction model and a test sample used to evaluate the predictive ability of the model. The best model for predicting the logarithm of age was a linear regression with otolith diameter. The prediction of daily age was more accurate for younger ( $<200$ days) juveniles. Overall, ages predicted from the model were unbiased in relation to ages determined from otolith microincrement counts. Moreover, predicted daily ages reproduced the overall shape of the observed age distribution and provided comparable growth estimates $\left(0.041 \mathrm{~cm}\right.$ day $\left.^{-1}\right)$. The back-calculated birthdate period ranged from 29 September 2003 to 22 July 2004, with a peak in January 2004, which is consistent with the spawning season. The model presented here could be used as a method for increasing the volume of juvenile daily age data. Since growth and survival varies spatially and temporally, relationships between age and otolith/fish morphometry should not be extrapolated outside sampled periods, areas and fish size/age.
\end{abstract}

Keywords: daily age; otoliths; sardine; otolith weight; otolith diameter; northern Portugal.

Predicción de la edad de juveniles de sardina (Sardina pilchardus) a partir de las características de los otolitos y las características morfométricas

Resumen: Un modelo de edad-predicción basado en las características individuales (longitud total; peso) y en las características de los otolitos (diámetro; peso) fue investigado para los juveniles de sardina, Sardina pilchardus (Walbaum, 1792). Juveniles fueron recolectados en el Norte de Portugal entre Mayo de 2004 y Enero de 2005 . Los anillos de crecimiento diarios fueron contados a partir de los otolitos correspondientes a 114 juveniles entre los $7-16 \mathrm{~cm}$ de longitud total. La muestra fue dividida en una muestra de entrenamiento para desarrollar el modelo de edad-predicción y una muestra de prueba usada para evaluar la habilidad predictiva del modelo. El mejor modelo para predecir el logaritmo de la edad fue un modelo de regresión lineal con el diámetro de otolito. La predicción de las edades diarias fue más precisa para los individuos más jóvenes $(<200$ días). En conjunto, las edades estimadas a partir del modelo no fueron significativamente diferentes de las determinadas con los contajes de microincrementos. Las edades diarias estimadas reprodujeron de forma correcta la distribución de las edades observadas y proporcionaron estimativas comparables de crecimiento $(0.041 \mathrm{~cm} \mathrm{dia-1})$. El retrocálculo del período de la fecha de nacimiento osciló entre el 29 de Septiembre de 2003 y el 22 de Julio de 2004, con un pico en Enero de 2004 , fecha consistente con el período reproductor. El modelo presentado en este estudio puede ser usado cómo un método para incrementar el volumen de datos referentes a edades diarias. Debido a las variaciones espaciales y temporales en el crecimiento y supervivencia de los individuos, las relaciones morfométricas referentes a edad-otolito/pez no deben ser extrapoladas fuera de los períodos de muestreo, áreas de muestreo y talla peces/edad.

Palabras clave: edad diaria; otolito; sardina; peso de otolito; diámetro de otolito; norte de Portugal.

Citation/Como citar este artículo: Silva A.V., Meneses I., Silva A. 2015. Predicting the age of sardine juveniles (Sardina pilchardus) from otolith and fish morphometric characteristics. Sci. Mar. 79(1): 35-42. doi: http://dx.doi.org/10.3989/ scimar.04143.16A

Editor: I. Palomera.

Received: August 30, 2014. Accepted: January 28, 2015. Published: February 23, 2015.

Copyright: () 2015 CSIC. This is an open-access article distributed under the Creative Commons Attribution-Non Commercial Lisence (by-nc) Spain 3.0. 


\section{INTRODUCTION}

Data on the birthdates of juvenile fish are important for investigating periods when environmental conditions are most favourable to recruit survival (Wilhelm et al. 2005, Baumann et al. 2008). Such knowledge is particularly important in the case of small pelagic fish such as sardine (Sardina pilchardus) that have extended spawning seasons and extensive inter-annual fluctuations in recruitment (Stratoudakis et al. 2007, ICES 2014). The assignment of age to juvenile fish is commonly based on counts of otolith daily growth rings, a time-consuming task which requires long training and experience (Jones 1992). Otolith and fish morphometric characteristics have been shown to be good predictors of age in adult fish of several species (Fossen et al. 2003, Lou et al. 2005, 2007, Steward et al. 2009, see review by Francis and Campana 2004). The idea of extending the technique to overcome the particularly difficult task of determining age in juvenile fish has been put forward by Pawson (1990). However, the few published applications on juvenile fish age prediction from morphometric characteristics that we are aware of (Fey and Linkowski 2006, Megalofonou 2006) indicate that the idea has received limited attention in the past two decades.

Sardine is an important fishing resource in Portugal, accounting for $40 \%$ of total fish landings in weight and $20 \%$ in first sales value (INE 2014). It is the target species of the purse seine fishery which operates in the coastal waters of the continental shelf. The northwest Portuguese waters encompass the main nursery area of the Iberian Peninsula sardine stock (Silva et al. 2009, ICES 2014). The concentration of juvenile fish in the area appears to result from the combination of retention mechanisms and high productivity associated with upwelling and river runoff (Álvarez and Alemany 1997, Santos et al. 2004, Bernal et al. 2007). Like most small pelagic fishes, sardine recruitment fluctuates extensively between years, partly driven by environmental conditions (Santos et al. 2012 and references therein). These fluctuations create great challenges to fisheries management (ICES 2014). Moreover, sardine is a key forage species for small cetaceans, seabirds and fishes (Preciado et al. 2008, Paiva et al. 2013) and shifts in its abundance may trigger cascading effects in the pelagic ecosystem.

Off Portugal, sardine has a protracted spawning season that can span half of the year from autumn to spring (Coombs et al. 2006, Stratoudakis et al. 2007). The identification of periods within the spawning season that produce successful recruitment will assist a targeted search of recruitment-environment relationships and help to raise hypotheses on the mechanisms that drive survival of early life stages and recruitment variability. The determination of age and birthdates of surviving recruits is a fundamental step towards achieving this aim. Age determination in juvenile sardine (Ré 1984, Alemany and Álvarez 1994, Alemany et al. 2006) has been hampered by the labour and cost associated with the processing of otoliths (Meneses 2003; Alemany et al. 2006).
This study aimed to identify the best model for predicting the age, in days, of sardine juveniles from otolith (diameter and weight) and fish (total length and weight) morphometric characteristics.

\section{MATERIALS AND METHODS}

An age prediction model was developed using samples of sardine juveniles collected off the northwest coast of Portugal during the 2004-2005 recruitment season (training sample) and was applied to predict the age of individuals in another sample collected in the same period and area (test sample). In both samples fish ages were determined by counting daily of rings on otoliths. The performance of the model was evaluated by comparing individual ages, age frequency distributions and growth derived from model-predicted ages and ages determined by daily ring counts on otoliths of the same individuals from the test sample. The model was applied to a larger sample of juveniles to describe the birthdate distribution of the survivors of the 2004 year-class.

\section{Sampling}

Juvenile sardines were collected from purse seine landings once or twice a month between May 2004 and January 2005 off the northwest coast of Portugal. Each time, 55-135 individuals were taken randomly from the catch of a single vessel and sorted into 0.5 $\mathrm{cm}$ total length classes. For the analysis of age and morphometric characteristics, 5-7 individuals were selected from the modal class and the tails of the length distribution of each of the samples (Table 1). In the samples collected on 27 May and 4 June all individuals were measured. Total length $\left(\mathrm{T}_{\mathrm{L}}\right.$, nearest $\left.0.1 \mathrm{~cm}\right)$, total weight $\left(\mathrm{W}_{\mathrm{T}}\right.$, nearest $\left.0.01 \mathrm{~g}\right)$, otolith weight $\left(\mathrm{O}_{\mathrm{W}}\right.$, nearest $0.0001 \mathrm{~g})$ and otolith diameter $\left(\mathrm{O}_{\mathrm{D}}\right.$, nearest 0.1 $\mu \mathrm{m})$ were recorded in a total of 240 individuals (Table 1). Annual growth rings were counted following the age reading protocol of the species (ICES 2011); all individuals were classified into the 2004 year-class, i.e. they belonged to age groups 0 or 1 .

Otolith daily growth rings were counted on a subset of 114 individuals spanning the study period as evenly as possible. This sub-set was divided into a training sample (TrS) of 58 individuals used to develop the age prediction model and a test sample (TsS) of 56 individuals used to evaluate the predictive ability of the model (Table 1).

\section{Otolith preparation and age reading}

The left sagittal otolith was extracted from each individual and cleaned in water with 2-3 drops of sodium hypochlorite (Secor et al. 1992). The otoliths were washed again with water and dried in an oven for 14 hours at $60^{\circ} \mathrm{C}$ followed by 1 hour in the desiccator. If the left otolith was damaged, the right otolith was weighed, as there was no significant difference between the weight of the right and left otoliths of each individual (Student- $\mathrm{t}=-0.066 ; \mathrm{n}=42, \mathrm{p}>0.05$ ). Otolith 
Table 1. - Sampling date, fish length range and number of sardine juveniles per sample. TrS, training sample; TsS, test sample; Ps, pooled sample. Total number includes the number of individuals in the TrS, TsS and Ps. *Total number of the remaining individuals ( $\mathrm{n}=126$ ) for which morphometric characteristics were recorded but age was not observed.

\begin{tabular}{|c|c|c|c|c|c|}
\hline Date & Fish length [range] $(\mathrm{cm})$ & $\operatorname{TrS}$ & $\mathrm{TsS}$ & Ps* & Total \\
\hline 20-05-2004 & {$[6.5-11.5]$} & 12 & & 4 & 16 \\
\hline $27-05-2004$ & {$[8-10]$} & 7 & 9 & 22 & 38 \\
\hline 04-06-2004 & [8-19.5] & & 9 & 35 & 44 \\
\hline $28-06-2004$ & {$[9-12.5]$} & 6 & 5 & 3 & 14 \\
\hline $01-07-2004$ & {$[7.3-9.2]$} & & & 11 & 11 \\
\hline 20-07-2004 & {$[8.5-13.5]$} & 9 & 3 & 1 & 13 \\
\hline $26-07-2004$ & {$[9.5-12.5]$} & & & 14 & 14 \\
\hline 24-08-2004 & {$[10-14.5]$} & 4 & 8 & 1 & 13 \\
\hline 06-09-2004 & {$[11-14.4]$} & & & 14 & 14 \\
\hline 23-09-2004 & [11-14] & 5 & 6 & 7 & 18 \\
\hline $16-11-2004$ & {$[11.5-16.5]$} & 3 & 2 & 10 & 15 \\
\hline $19-11-2004$ & {$[11-14.5]$} & 4 & 10 & 2 & 16 \\
\hline $10-01-2005$ & [9-13] & 8 & 4 & 2 & 14 \\
\hline Total & & 58 & 56 & 126 & 240 \\
\hline
\end{tabular}

diameter, the distance between the furthest edges of anterior and posterior zones, passing through the nucleus, was measured with a calibrated image analysis system using Visilog (version 6.3; Noesis; www.noesis.fr) (Fig. 1). Otoliths were mounted on a glass plate with Entellan ${ }^{\circledR}$ (with the sulcus acousticus facing down) and polished with lapping film of 30,9 and $0.3 \mu \mathrm{m}$ grit until

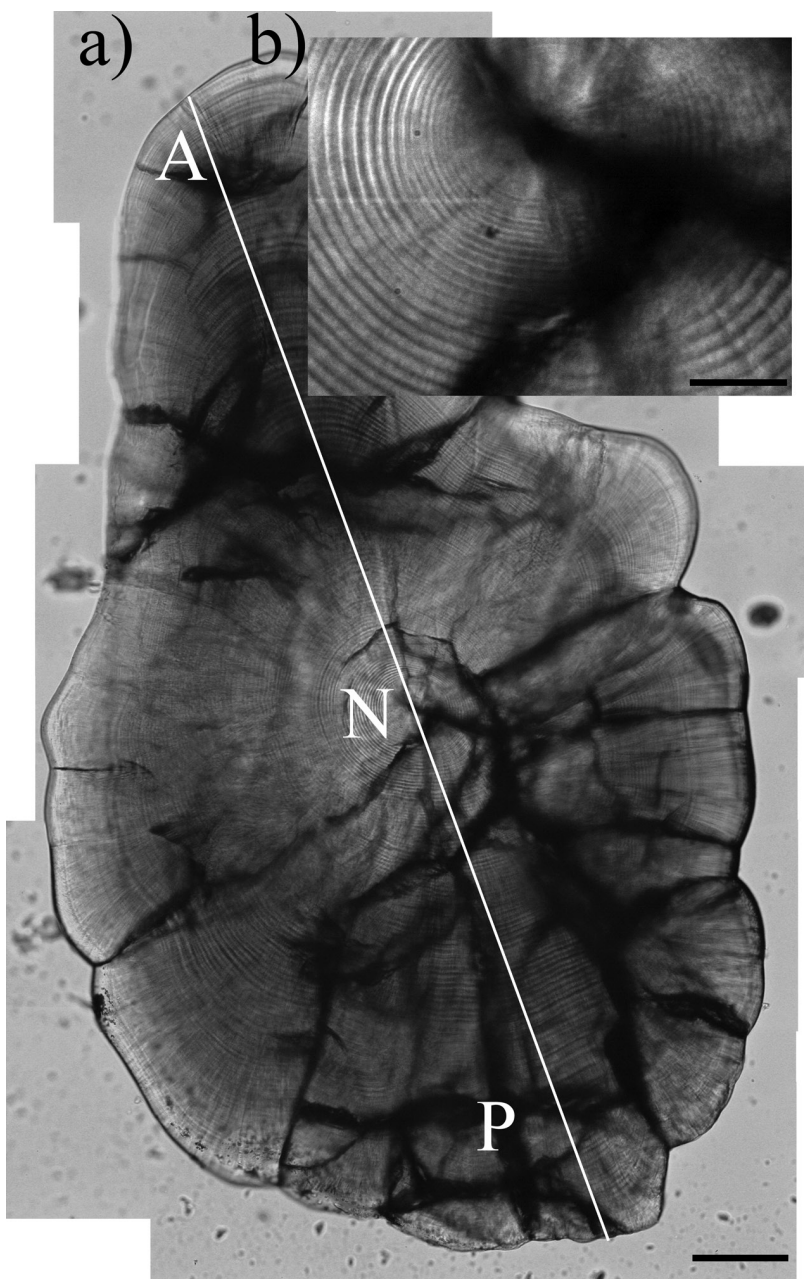

Fig. 1. - Composite micrograph of the otolith of a juvenile sardine, assembled from 26 micrographs of parts of the otolith (scale bar $=100$ um) (a) and micrograph of the central area of the otolith. Amplification, $200 \times$ (scale bar $=50 \mu \mathrm{m}$ ) (b). A, anterior edge; P, posterior edge;

$\mathrm{N}$, nucleus. Line indicates otolith diameter. Amplification, 400×. the growth increments and the nucleus became visible. Sequences of 50-60 micrographs of partial areas of the otolith were taken with a microscope with a magnification of $200 \times$ and manually combined to obtain a single picture of the whole otolith (Fig. 1). Daily growth rings were identified following criteria outlined in Ré (1984). Daily rings were counted from the nucleus to the posterior edge (Fig. 1). Occasionally, daily increments were difficult to resolve. In such cases ring counts were linearly interpolated based on the widths of previous and subsequent clearly visible daily rings. Daily ages were calculated from the total number of rings plus 5 days, the average period of the endogenous feeding (Ré 1986).

The process of weighing and measuring a sample of 20 otoliths took 2 working days, on average. Otolith preparation and determination of daily rings of the same number of otoliths took 11 working days.

\section{Data analyses}

Spearman correlation coefficients were calculated for all pairwise combinations of age, $\mathrm{T}_{\mathrm{L}}, \mathrm{W}_{\mathrm{T}}, \mathrm{O}_{\mathrm{D}}$ and $\mathrm{O}_{\mathrm{W}}$. A multiple linear regression model was fitted to age of $\mathrm{TrS}$ individuals using the four morphometric characteristics as additive effects. Model residuals were checked graphically. Age was log-transformed to comply with assumptions of normality and homogeneity of error variance. The model was selected by minimizing the Akaike Information Criterion (AIC).

The final model was used to predict the age of individuals from the TsS using morphometric measurements. Three approaches were used to compare model-predicted ages with ages determined by daily ring counts (hereby termed observed ages) of fish from the TsS: (i) differences between predicted and observed ages were tested using a pairwise Wilcoxon rank sum test, (ii) the frequency distributions of predicted and observed ages were compared using a Kolmogorov-Smirnov test and (iii) Gompertz growth models were fitted to predicted and observed ages versus length and compared using a likelihood ratio test. The Gompertz model fitted to age-length data has the following form:

$$
\mathrm{L}_{\mathrm{t}}=\mathrm{L}_{\infty} * \exp \left(-\exp \left(-\mathrm{G}^{*}\left(\mathrm{t}-\mathrm{t}_{0}\right)\right)\right)
$$


Table 2. - Summary statistics of sardine morphometric characteristics and age in the training sample, test sample and pooled sample. $\mathrm{T}_{\mathrm{L}}$, total fish length; $\mathrm{T}_{\mathrm{W}}$, total fish weight; $\mathrm{O}_{\mathrm{D}}$, otolith diameter; $\mathrm{O}_{\mathrm{w}}$, otolith weight; $\mathrm{SD}$, standard deviation. Ages predicted by the model are in bold.

\begin{tabular}{lccccccccc}
\hline & \multicolumn{2}{c}{ Training Sample } & \multicolumn{3}{c}{ Test Sample } & \multicolumn{3}{c}{ Pooled Sample } \\
& Mean \pm SD & Min. & Max. & Mean \pm SD & Min. & Max. & Mean \pm SD & Min. & Max. \\
\hline $\mathrm{T}_{\mathrm{L}}(\mathrm{cm})$ & $10.6 \pm 2.0$ & 6.7 & 15.6 & $11.7 \pm 1.8$ & 8.0 & 14.6 & $10.9 \pm 2.0$ & 7.3 & 15.8 \\
$\mathrm{~T}_{\mathrm{W}}(\mathrm{g})$ & $9.4 \pm 5.3$ & 1.8 & 26.3 & $11.8 \pm 5.1$ & 3.0 & 22.3 & $7.5 \pm 6.3$ & 2.6 & 30.4 \\
$\mathrm{O}_{\mathrm{D}}(\mu \mathrm{m})$ & $1763.7 \pm 405.7$ & 976.3 & 2529.3 & $1947.0 \pm 337.0$ & 1297.0 & 2447.0 & $1795.0 \pm 322.5$ & 1287.0 & 2597.0 \\
$\mathrm{O}_{\mathrm{W}}(\mathrm{mg})$ & $0.46 \pm 0.21$ & 0.12 & 0.98 & $0.56 \pm 0.20$ & 0.22 & 0.88 & $0.47 \pm 0.19$ & 0.22 & 1.06 \\
Age (days) & $177.6 \pm 43.6$ & 109.0 & 280.0 & $191.4 \pm 39.7$ & 124.0 & 272.0 & $178.4 \pm 34.7$ & $\mathbf{1 3 1 . 0}$ & $\mathbf{2 7 8 . 0}$ \\
\hline
\end{tabular}

Table 3. - Pairwise Spearman rank correlation coefficients of morphometric characteristics and age of juvenile sardines from the training sample. $\mathrm{T}_{\mathrm{L}}$, total fish length; $\mathrm{T}_{\mathrm{W}}$, total fish weight; $\mathrm{O}_{\mathrm{D}}$, otolith diameter; $\mathrm{O}_{\mathrm{w}}$, otolith weight.

\begin{tabular}{ccccc}
\hline & $\mathrm{T}_{\mathrm{W}}$ & $\mathrm{O}_{\mathrm{D}}$ & $\mathrm{O}_{\mathrm{W}}$ & Age \\
\hline $\mathrm{T}_{\mathrm{L}}$ & 0.99 & 0.91 & 0.94 & 0.86 \\
$\mathrm{~T}_{\mathrm{W}}$ & & 0.89 & 0.92 & 0.87 \\
$\mathrm{O}_{\mathrm{D}}$ & & & 0.97 & 0.90 \\
$\mathrm{O}_{\mathrm{W}}$ & & & & 0.90 \\
\hline
\end{tabular}

where $\mathrm{L}_{\mathrm{t}}$ is total fish length, $\mathrm{L}_{\infty}$ is asymptotic length, $\mathrm{G}$ is the instantaneous rate of growth at age $\mathrm{t}_{0}, \mathrm{t}_{0}$ is the inflection point of the curve and the age at which absolute growth rate begins to decline (the age of maximal growth) (Ricker 1979). A likelihood ratio test (Kimura 1980) was used to compare growth models. The hypothesis of separate curves for predicted and observed ages was set as a base case and tested against the alternative of simultaneous equality of the four growth parameters (i.e. whether the curves are coincident and therefore a single growth curve fits best the data). If this hypothesis was rejected, further tests could be carried out to evaluate differences between curves in each growth parameter at a time $\left(\mathrm{L}_{\infty}, \mathrm{G}, \mathrm{t}_{0}\right)$. The mean absolute growth rate, between $\mathrm{L}_{1}$ and $\mathrm{L}_{2}$, g, was calculated as:

$$
\mathrm{g}=\mathrm{G}^{*} \mathrm{~L}_{1} *\left(\operatorname{lnL} \mathrm{L}_{2}-\ln \mathrm{L}_{1}\right)
$$

where $\mathrm{L}_{1}$ and $\mathrm{L}_{2}$ are predicted lengths at ages 124 and 272 days (minimum and maximum observed ages in pooled $\mathrm{TrS}$ and $\mathrm{TsS}$ ).

Finally, to describe the birthdate distribution of the survivors of the 2004 year-class, the age prediction model was used to predict the ages of the remaining 126 individuals (pooled sample; Ps), for which only body and otolith measurements were available (Table 1). Ages (predicted and observed) were pooled from all samples to build the birthdate distribution of sardine. Individual birthdates were calculated by subtracting the age from the date of sampling.

Computations and statistical analyses were carried out using R software 2.15.0 (R Development Core Team 2008). The significance level was 0.05 in all tests of hypothesis.

\section{RESULTS}

The summary statistics of age and morphometric characteristics of sardine juveniles in the TrS and TsS are presented in Table 2. Mean values of fish and otolith morphometric characteristics were slightly smaller in the TrS than in the TsS. However, the ranges were similar in the two samples, indicating only minor extrapolation when the age prediction model was used to estimate age of fish in the Ps. In the TrS the length of sardine juveniles ranged from 6.7 to $15.6 \mathrm{~cm}$, corresponding to predicted ages of between 109 and 280 days (broadly 3.6 to 9.3 months).

Morphometric characteristics were significantly positively correlated both with each other and with fish age (Table 3). Otolith characteristics tend to have slightly higher correlations with age than body size characteristics. The final age prediction model, $\ln ($ age $)=0.00057 \mathrm{O}_{\mathrm{D}}+4.14$, included only $\mathrm{O}_{\mathrm{D}}$ as an independent variable. The regression in otolith diameter explained $86 \%$ of the variance of sardine juveniles' age (Fig. 2). Differences between model-predicted ages and observed ages, termed absolute age estimation errors, for the TsS ranged from -45 days to +47 days and overall were not significant at the $5 \%$ level $(n=56$, $\mathrm{p}>0.17$ ). Model-predicted ages were within an interval of \pm 7 days around the observed ages for $55.4 \%$ of the fish and within an interval of \pm 15 days for $69.6 \%$ of the fishes. Absolute age estimation errors were generally

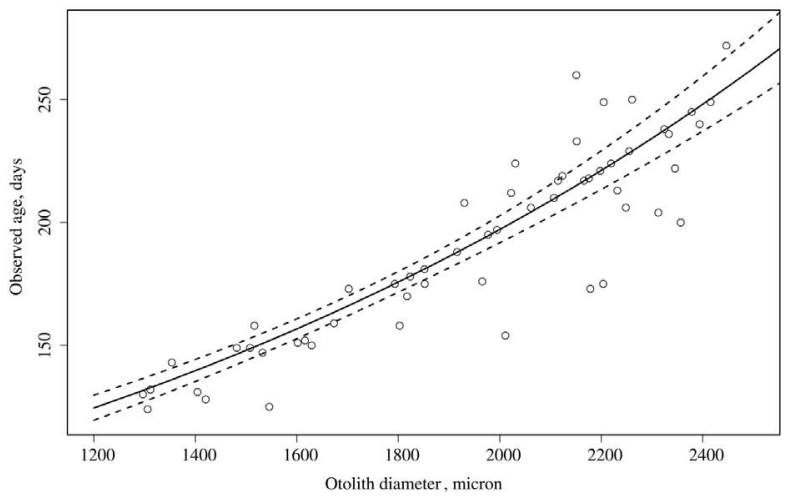

Fig. 2. - Relationship between age and otolith diameter for juvenile sardines in the TsS sample. Solid line, back-transformed age predicted by the regression on otolith diameter; dashed lines, predicted age \pm 2 se; symbols, observed values.

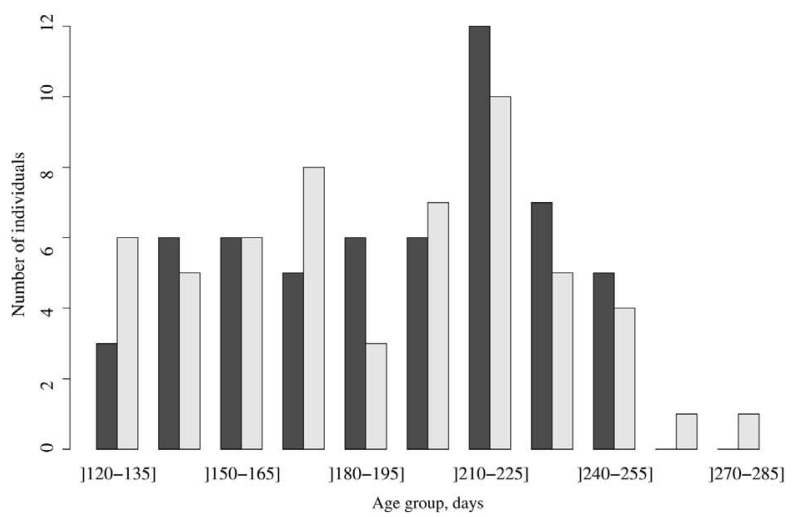

Fig. 3. - Distribution of observed (grey bars) and model-predicted (black bars) ages of sardine juveniles in the test sample. 
Table 4. - Coefficients of the Gompertz growth model for the samples. TrS, training sample; TsS, test sample; Ps, pooled sample.

\begin{tabular}{|c|c|c|c|c|c|c|c|}
\hline \multirow[b]{2}{*}{ Samples } & \multicolumn{2}{|c|}{$\mathrm{L}_{\infty}(\mathrm{cm})$} & \multicolumn{2}{|c|}{$\mathrm{G}\left(\mathrm{cm} \mathrm{day}^{-1}\right)$} & \multicolumn{2}{|c|}{$\mathrm{t}_{0}$ (days) } & \multirow[t]{2}{*}{$\mathrm{r}^{2}$} \\
\hline & Estimate & $95 \% \mathrm{CI}$ & Estimate & $95 \% \mathrm{CI}$ & Estimate & $95 \% \mathrm{CI}$ & \\
\hline $\operatorname{TrS}$ & 13.8 & {$[12.9,16.2]$} & 0.021 & {$[0.01,0.03]$} & 92.8 & {$[68.2,107.0]$} & 0.72 \\
\hline TsS & 14.9 & {$[13.7,18.4]$} & 0.016 & {$[0.01,0.02]$} & 100.1 & {$[88.4,109.8]$} & 0.86 \\
\hline Ps & 14.3 & {$[13.5,16.0]$} & 0.018 & {$[0.01,0.02]$} & 94.4 & {$[81.9,104.1]$} & 0.78 \\
\hline
\end{tabular}

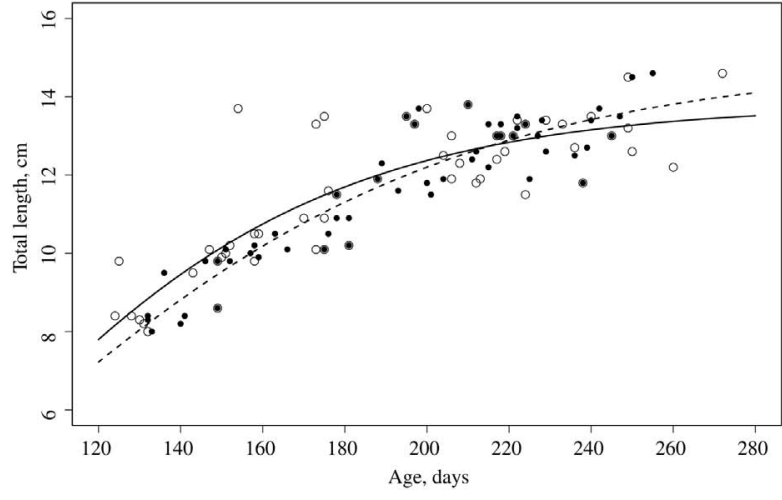

Fig. 4. - Gompertz growth curves of juvenile sardine based on observed ages (open circles and solid line) and model-predicted ages (full circles and dashed line).

greater in older individuals; for example, the median error was 6 days for fishes younger than 200 days (first and third quantiles were 1 and 9 days, respectively) and 12.3 days for fishes older than 200 days (first and third quantiles were 0.5 and 19.5 days, respectively).

The frequency distributions of predicted and observed ages were not significantly different $(D=0.11$, $\mathrm{n}=58, \mathrm{p}=0.90$ ). The age distribution predicted by $\mathrm{O}_{D}$ reflects the overall shape of the observed age distribution despite some smoothing (Fig. 3).

The Gompertz model provided a good description of the length-age relationship of sardine juveniles from the TrS and TsS and the Ps, as indicated by corresponding $\mathrm{r}^{2}$ values (Table 4; Fig. 4). The likelihood ratio test indicated that growth curves based on predicted and observed ages were coincident $(\mathrm{p}=0.08)$. The Gompertz model estimates a maximum growth rate of $0.018 \mathrm{~cm}$ day $^{-1}$ at 94.4 days, but implies some extrapolation from the observed range of ages. The instantaneous mean growth rate of juveniles between $7.9 \mathrm{~cm}$ (124 days)

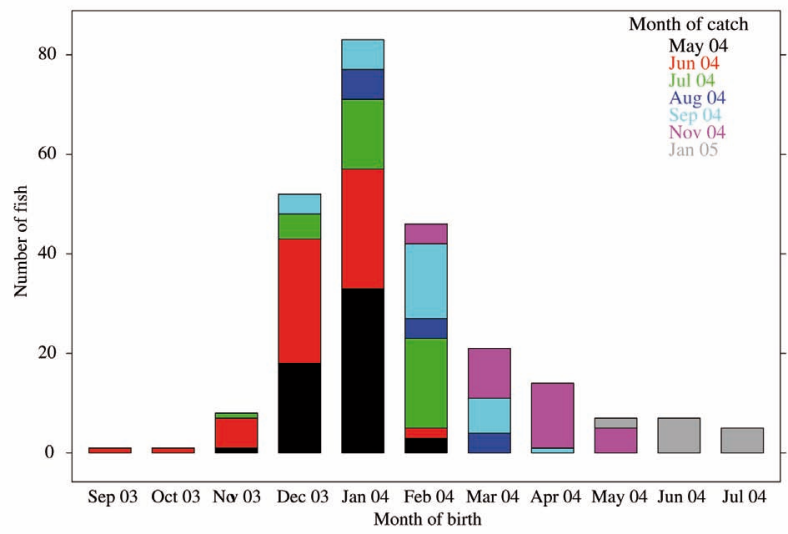

Fig. 5. - Monthly frequency distribution of birthdates of sardine juveniles. Each bar shows the proportion of individuals originating from each sampling month. and $13.7 \mathrm{~cm}$ (272 days) is $0.077 \mathrm{~cm} \mathrm{day}^{-1}$. The average growth rate of juvenile sardine in the same time interval was $0.041 \mathrm{~cm} \mathrm{day}^{-1}$.

The age of all sardine juveniles sampled in this study ranged from 109 to 280 days, corresponding to birthdates between 29 September 2003 and 22 July 2004 (Fig. 5). Daily ages indicate that $74 \%$ of the individuals were born in 2004 and the remainder were born in 2003. The monthly birthdate distribution shows a peak in January 2004. There is a relationship between the month of capture and the birthdate, i.e. juveniles caught earlier in the year, for example in May-June, were born in the early birth season, September-January, while those caught later in the year, August-November, were born in the late birth season, March-May.

\section{DISCUSSION}

Morphometric characteristics examined in this study, otolith weight and diameter and fish total length and weight, were linearly related to the logarithm of age in sardine juveniles 109-280 days old. Otolith characteristics were better correlated with age than fish characteristics. The best model for predicting the age of sardine juveniles was found for otolith diameter $\left(\mathrm{O}_{\mathrm{D}}\right)$. Overall, ages predicted from the model for new individuals were unbiased in relation to ages determined from otolith examination. Moreover, predicted ages reproduced the overall shape of the observed age distribution and provided comparable growth estimates. The results also indicate that the prediction of daily age from otolith diameter is more accurate for younger ( $<200$ days) than for older juveniles.

Most studies examining relationships between fish age and individual and otolith measurements have focused on annual ages and suggest otolith weight to be a better age predictor than otolith linear dimensions and fish morphometry. For example, otolith weight explained $70 \%$ to $90 \%$ of the variability in the age of adults of pelagic species such as Sardinops sagax neopilchardus (Fletcher 1995), Trachurus symmetricus and Trachurus mediterraneus (Kasapoglu and Duzgunes 2013). The fact that the otolith grows continually over the life of fish while body growth slows down explains the better relationship of age with otolith dimensions than with fish body dimensions (Secor and Dean 1989). Moreover, among fish of the same length, older fish tend to have bigger otoliths, meaning that otolith dimensions are more tightly coupled with fish age than body dimensions (Templeman and Squires 1956). Otolith growth will eventually uncouple with fish growth and a variety of factors, such as temperature and feeding conditions, influence the degree or timing of this uncoupling (Moksness et al. 1995). Linear dimensions are likely to uncouple earlier than otolith weight be- 
cause as fish grow, otolith growth may not accumulate in the anterior-posterior axes (length), but rather continue to accrete to the medial axis (thickness, which is revealed in weight) (Wright et al. 1990, Fletcher 1991, 1995, Wilson et al. 2009).

During the juvenile phase growth is fast and continuous, so both body and otolith morphometric characteristics are expected to have a strong association with fish age. In fact, the results of Fey and Linkowski (2006) for Baltic cod (Gadus morhua), Megalofonou (2006) for bluefin tuna (Thunnus thynnus) and those for sardine in the present study show that different otolith measurements and even individual fish measurements have a more similar performance as age predictors in the case of juvenile fish than in the case of adult fish. For Baltic cod and tuna, otolith weight was still the best daily age predictor. In the case of sardine, otolith diameter was the single variable retained in the multiple regression, with log age reflecting a slight advantage over otolith weight and a moderate advantage over body morphometric characteristics in terms of model fit. Having a single variable, the final age prediction model for sardine juveniles is exempt of colinearity issues. Moreover, due to the particularly small size of sardine otoliths, weighing is more difficult and timeconsuming than measuring as it involves extra handling of otoliths. Weighing further requires a high precision analytical balance, which may not be available in a fish biology laboratory. Finally, although body morphometric characteristics are globally the easiest and fastest to measure, we consider that the higher explanatory power of otolith diameter outweighs the advantages of fish body measurements for predicting the age of sardine juveniles.

Age-otolith size relationships may change seasonally as a result of changes in temperature, food availability or size/growth-selective mortality during larval stages (Campana and Neilson 1985). Growth-selective mortality has been described at earlier larval stages in sardine from the northern Alboran Sea (Ramírez et al. 2001); slow-growing larvae, which thus have smaller otoliths at age, undergo higher mortality than fastgrowing larvae and are therefore under-represented in older age groups. Unfortunately, the limited number of otoliths sampled per month prevented the investigation of seasonal changes in the age-otolith diameter relationship presented here for sardine. Nevertheless, we do not expect important biases since the majority of otoliths were sampled during a relatively short period of time ( 4-5 months), mostly during summer when local environmental conditions do not change dramatically (Gago et al. 2011).

Despite the use of a regression model, predicted ages were not affected by "centric bias", the tendency to overestimate (underestimate) the dependent variable for large (small) values of the independent variable (Francis and Campana 2004), possibly due to the high correlation between age and otolith diameter. Predicted ages were close to observed ages in most of the younger juveniles ( $<200$ days). However, the performance of otolith diameter deteriorated in older juveniles, with errors above \pm 20 days for $25 \%$ of $>200$-day-old individuals and a few very imprecise predictions. The increasing difference between predicted and observed age could reflect gradual uncoupling of otolith growth from fish growth, as seen, for example, in juvenile cod (e.g. Fey and Linkowski 2006). Uncoupling was not observed in sardine larvae (Ramírez et al. 2001) but it might occur in juveniles. However, this possibility is contradicted by the close linear relationship between otolith and somatic growth in sardine juveniles with a similar length to those analysed in the present study (Alemany et al. 2006). On the other hand, the increasing discrepancy between predicted and observed ages is more likely to reflect a decrease in accuracy of observed ages in older individuals. Microincrements become increasingly difficult to read in older juveniles due to the slowdown of growth, which blurs the opaque and translucent zones and to the potential presence of false rings associated with the first maturity. These difficulties may lead to under- or overestimation of the true age, and therefore a biased birthdate distribution. However, the net result is uncertain and its clarification requires the validation of age in these older individuals.

Mean lengths at age and growth rates estimated in the present study are within the range of those reported for sardine juveniles of similar age in Portuguese waters and neighbouring areas. The linear mean growth rate estimated from the pooled sample, 0.041 $\mathrm{cm} \mathrm{day}^{-1}$, for 109-280 days old sardines is higher than that estimated for juveniles from the central western Portuguese waters, $0.024 \mathrm{~cm} \mathrm{day}^{-1}$ for sardines of 142-277 days (Meneses 2003), but lower than that of juveniles sampled off Galicia, $0.054 \mathrm{~cm} \mathrm{day}^{-1}$ for sardines of 150-300 days (Álvarez and Alemany 1997). A growth rate similar to that obtained in this study, $0.040 \mathrm{~cm} \mathrm{day}^{-1}$ for 116-294 days old sardine, was reported for the Alboran Sea, southeastern Mediterranean (Alemany et al. 2006). Daily ages obtained in this study confirmed the classification of juveniles in the 2004 year-class for most individuals (75\%). Fortnightly age distributions of predicted ages are not significantly different from those of observed ages despite some underestimation in the youngest and oldest age groups. Nevertheless, the general pattern of bias does not indicate smoothing bias that can be generated by the use of simple regression models for age prediction (Francis and Campana 2004).

The distribution of birthdates of sardine juveniles sampled in this study is broadly consistent with the species spawning season in the Portuguese waters, which takes place from October to March, with a maximum between December and February (Coombs et al. 2006, Stratoudakis et al. 2007, Nunes et al. 2011). Samples collected along the recruitment season, from May 2004 to January 2005, show the progress of birthdates over the spawning season, from September 2003 to July 2004. Most of the survivors were born between December 2003 and February/March 2004, with a peak in January. Interestingly, juveniles sampled in the latest months of the recruitment season were born between May and July, i.e. outside the main spawning season. Though few females are reproductively active during summer months (Nunes et al. 2011), successful births 
in summer might be explained by higher survival of early life stages due to improved female condition (Nunes et al. 2011), higher temperatures and the onset of the upwelling season (Relvas et al. 2009). Nevertheless, the above findings should be viewed with caution since our sampling was not designed for a quantitative estimation of the juveniles' birthdate distribution.

The assignment of age from counts of daily growth rings is a complex and time-consuming procedure limiting the development of studies on growth and survival of juveniles. The collection of fish and otolith morphometry is simpler, faster and more cost-effective.

In conclusion otolith diameter used in a simple linear regression predicted the age of sardine juveniles with good precision and provided reliable estimates of their age/birthdate distribution and growth. The method is more precise for younger juveniles ( $<200$ days old), although the appropriate precision of age determination depends on the prospective use of the data. Fish growth varies spatially and temporally and may depend on year-class abundance, thus precluding extrapolation of age-otolith relationships outside the range of observed periods, areas and fish size/age. The method presented here may be viewed as a way to complement daily ring counts in order to increase the volume of data. Further studies need to be carried out to examine seasonal changes in the relationship between age and morphometric characteristics for sardine.

\section{ACKNOWLEDGEMENTS}

Data analysed in this work were obtained through the Portuguese sampling programme PNAB, integrated in the EU Data Collection/DCF Programme. The authors thank the IPMA team who contributed to the collection and laboratory analysis of the biological samples used in this study. We are also grateful to $\mathrm{S}$. Rodríguez-Climent for the Spanish abstract. Finally, we thank the two anonymous reviewers who provided many helpful comments and improved the quality of the final manuscript.

\section{REFERENCES}

Alemany F., Álvarez F. 1994. Formation of initial daily increments in sagittal otoliths of reared and wild Sardina pilchardus yolksac larvae. Mar. Biol. 121: 35-39. http://dx.doi.org/10.1007/BF00349471

Alemany F., Álvarez I., García A., et al. 2006. Post larvae and juvenile daily growth patterns of the Alboran Sea sardine (Sardina pilchardus, Walbaum): influence of wind. Sci. Mar. 70S2: 93-104.

Álvarez F., Alemany F. 1997. Birthdate analysis and its application to the study of recruitment of the Atlanto-Iberian sardine, Sardina pilchardus. Fish. Bull. 95: 187-194.

Baumann H., Voss R., Hinrichsen H.-H., et al. 2008. Investigating the selective survival of summer- over spring-born sprat, Sprattus sprattus, in the Baltic Sea. Fish. Res. 91: 1-14. http://dx.doi.org/10.1016/j.fishres.2007.11.004

Bernal M., Stratoudakis Y., Coombs S., et al. 2007. Sardine spawning off the European Atlantic coast: Characterization of and spatio-temporal variability in spawning habitat. Prog. Oceanogr. 74: 210-227. http://dx.doi.org/10.1016/j.pocean.2007.04.018

Campana S.E., Neilson J.D. 1985. Microstructure of fish otoliths. Can. J. Fish Aquat. Sci. 42: 1014-1032. http://dx.doi.org/10.1139/f85-127

Coombs S.H., Smyth T.J., Conway D.V.P., et al. 2006. Spawning season and temperature relationships for sardine (Sardina pilchardus) in the eastern North Atlantic. J. Mar. Biol. Assoc. U. K. 86: 1245-1252. http://dx.doi.org/10.1017/S0025315406014251

Fey D.P., Linkowski T.B. 2006. Predicting juvenile Baltic cod (Gadus morhua) age from body and otolith size measurements. ICES J. Mar. Sci. 63:1045-1052.

Fletcher W.J. 1991. A test of the relationship between otolith weight and age for the Pilchard Sardinops neopilchardus. Can. J. Fish. Aquat. Sci. 48: 35-38. http://dx.doi.org/10.1139/f91-005

Fletcher W.J. 1995. Application of the otolith weight-age relationship for the Pilchard, Sardinops sagax neopilchardus. Can. J. Fish. Aquat. Sci. 52: 657-664. http://dx.doi.org/10.1139/f95-066

Fossen I., Albert O., Nilssen E. 2003. Improving the precision of ageing assessments for long rough dab by using digitalized pictures and otoliths measurements. Fish. Res. 60: 53-64. http://dx.doi.org/10.1016/S0165-7836(02)00063-2

Francis R.I.C., Campana S.E. 2004. Inferring age from otolith measurements: a review and a new approach. Can. J. Fish. Aquat. Sci. 91: 1269-1284. http://dx.doi.org/10.1139/f04-063

Gago J., Cabanas J.M., Casas G., et al. 2011. Thermohaline measurements in the continental shelf zone of the NW Iberian Peninsula, 1994-2006. Clim. Res. 48: 219-229. http://dx.doi.org/10.3354/cr00943

ICES 2011. Report of the Workshop on Age Reading of European Atlantic Sardine (WKARAS), 14-18 February 2011, Lisbon, Portugal. ICES CM 2011/ACOM: 42, 91 pp.

ICES 2014. Report of the Working Group on Southern Horse Mackerel, Anchovy, and Sardine (WGHANSA), 20-25 June 2014, Copenhagen, Denmark. ICES CN 2014/ACOM: 16, 532 pp.

INE 2014. Estatísticas da pesca 2013. Instituto Nacional de Estatística, I.P., Lisbon, Portugal, 135 pp.

Jones C.M. 1992. Development and application of the otolith increment technique. In: Stevenson D.K., Campana S.E. (eds). Otolith microstructure examination and analysis. Can. J. Fish. Aquat. Sci. 117: 1-11.

Kasapoglu N., Duzgunes E. 2013. The relationship between somatic growth and otolith dimensions of Mediterranean horse mackerel (Trachurus mediterraneus) from Black Sea. J. App. Ichthyol. 29: 230-233. http://dx.doi.org/10.1111/jai.12019

Kimura D.K. 1980. Likelihood methods for the Von Bertalanfy growth curve. Fish. Bull. 77: 765-776.

Lou D.C., Mapstone B.D., Russ G.R., et al. 2005. Using otolith weight-age relationship to predict age-based metric of coral reef fish populations at different spatial scales. Fish. Res. 71: 279-294. http://dx.doi.org/10.1016/j.fishres. 2004.09.003

Lou D.C., Mapstone B.D., Russ G.R., et al. 2007. Using otolith weight-age relationships to predict age based metrics of coral reef fish populations across different temporal scales. Fish. Res. 83: $216-227$.

http://dx.doi.org/10.1016/j.fishres.2006.09.017

Megalofonou P. 2006. Comparison of otolith growth and morphology with somatic growth and age in young-of-the-year bluefin tuna. J. Fish Biol. 68: 1867-1878. http://dx.doi.org/10.1111/j.1095-8649.2006.01078.x

Meneses I. 2003. Estimação de factores que Condicionam a Variabilidade do Recrutamento de Peixes na Costa Atlântica da Península Ibérica. PhD Thesis, Portuguese Institute for Fisheries and Sea Research (IPIMAR), Lisbon, Portugal.

Moksness E., Rukan K., Ystanes L., et al. 1995. Comparison of somatic and otolith growth in North Sea herring (Clupea herengus L.) larvae: evolution of growth dynamics in mesocosms. In: Secor D.H., Dean J.M., Campana S.E. (eds), Recent Developments in Fish Otolith Research. University of South Carolina Press, pp. 119-134.

Nunes C., Silva A., Soares E., et al. 2011. The use of hepatic and somatic indices and histological information to characterize the reproductive dynamics of Atlantic Sardine Sardina pilchardus from the Portuguese coast. Mar. Coast. Fish. 3: 127-144. http://dx.doi.org/10.1080/19425120.2011.556911

Paiva V.H., Werner A., Geraldes P., et al. 2013. Overcoming difficult times: The behavioural resilience of a marine predator when facing environmental stochasticity. Mar. Ecol. Prog. Ser. 
486: $277-288$

http://dx.doi.org/10.3354/meps10332

Pawson M.G. 1990. Using otolith weight to age fish. J. Fish Biol. 36: $521-531$.

http//dx doi.org/10.1111/j.1095-8649 1990 tb03554 x

Preciado I., Velasco F., Olaso I. 2008. The role of pelagic fish as forage for demersal fish community in the southern Bay of Biscay. J. Mar. Syst. 72: 407-417. http://dx.doi.org/10.1016/j.jmarsys.2007.04.007

Ramírez T., Cortés D., Garcia A. 2001. Growth of North Alboran Sea sardine larvae estimated by otolith microstructure, nucleic acids and protein content. J. Fish Biol. 59: 403-415. http://dx.doi.org/10.1111/j.1095-8649.2001.tb00139.x

R Development Core Team. 2008. R: A language and environment for statistical computing. R Foundation for Statistical Computing, Vienna, Austria. URL http://www.R-project.org

Ré P. 1984. Evidence of daily and hourly growth in pilchard larvae based on otolith growth increments, Sardina pilchardus (Walbaum, 1792). Cybium 8: 33-38.

Ré P. 1986. Otolith microstructure and detection of life history events in sardine and anchovy larvae. Ciênc. Biol. Ecol. Syst. 6: 9-17.

Relvas P., Luís J., Santos A.M.P. 2009. Importance of the mesoscale in the decadal changes observed in the northern Canary upwelling system. Geophys. Res. Lett. 36: L22601. http://dx.doi.org/10.1029/2009GL040504

Ricker W.E. 1979. Growth rates and models. In: Hoar W.S., Randal D.J., Brett J.R. (eds) Fish Physiology, Vol III Bioenergetics an Growth. Academic Press, pp. 677-744.

Santos M.A., Peliz A., Dubert J., et al. 2004. Impact of a winter upwelling event on the distribution and transport of sardine, (Sardina pilchardus) eggs and larvae of western Iberia: a retention mechanism. Cont. Shelf Res. 24: 149-165. http://dx.doi.org/10.1016/j.csr.2003.10.004

Santos M.B., Gonzalez-Quiros R., Riveiro I., et al. 2012. Cycles, trends, and residual variation in the Iberian sardine (Sardina pilchardus) recruitment series and their relationship with the environment. ICES J. Mar. Sci. 69: 739-750.

http://dx.doi.org/10.1093/icesjms/fsr186
Secor D. H., Dean J. M. 1989. Somatic growth effects on the otolithfish size relationship in young pond-reared striped bass, Morone saxatilis. Can. J. Fish. Aquat. Sci. 46: 113-121 http://dx.doi.org/10.1139/f89-015

Secor D.H., Dean J.M., Laban E.H. 1992. Otolith removal and preparation for microstructural examination. In: Stevenson D.K., Campana S.E. Otolith Microstructure examination and analysis. (eds). Can. Spec. Publ. Fish. Aquat. Sci. 117: 19-57.

Silva A., Skagen D.W., Uriate A., et al. 2009. Geographic variability of sardine dynamics in the Iberian Biscay region. ICES J. Mar. Sci. 63: 663-676. http://dx. doi.org/10.1016/jicesims. 2006.01.005

Steward C.A., DeMaria Karen D., Shenker J.M. 2009. Using otolith morphometrics to quickly and inexpensively predict age in the gray angelfish (Pomacanthus arcuatus). Fish. Res. 99: 123-129. http://dx.doi.org/10.1016/j.fishres.2009.05.011

Stratoudakis Y., Coombs S., Lago de Lanzós A., et al. 2007. Sardine (Sardina pilchardus) spawning seasonality in European waters of the northeast Atlantic. Mar. Biol. 152: 201-212. http://dx.doi.org/10.1007/s00227-007-0674-4

Templeman W., Squires H.J. 1956. Relationship of otolith length and weights in the haddock Melanogrammus aeglefinus (L.) to the rate of the growth of the fish. J. Fish Res. Board Can. 13: 467-487. http://dx.doi.org/10.1139/f56-029

Wilhelm M.R., Painting S.J., Field J.G., et al 2005. Impact of environmental factors on survival of larval and juvenile Cape anchovy Engraulis encrasicolus (G.) in the southern Benguela upwelling region, determined from hatchdate distributions: implications for recruitment. Mar. Freshwater Res. 56: 561-572. http://dx.doi.org/10.1071/MF04145

Wilson J.A., Vigliola L., Meekan M.G. 2009. The back-calculation of size and growth from otoliths: validation and comparison on models at an individual level. J. Exp. Mar. Biol. Ecol. 368: 9-21. http://dx.doi.org/10.1016/j.jembe.2008.09.005

Wright P.J., Metcalfe N.B., Thorpe J.E. 1990. Otolith and somatic growth rates in Atlantic salmon parr, Salmo salar L.: evidence against coupling. J. Fish Biol. 36: 241-249. http://dx.doi.org/10.1111/j.1095-8649.1990.tb05599.x 